\title{
Nutrient timing habits of Division I NCAA athletes
}

\author{
M G Nystrom", AR Jagim², M Greenwood ${ }^{3}$, J M Oliver ${ }^{1}$, MT Jones ${ }^{4}$ \\ From The Twelfth International Society of Sports Nutrition (ISSN) Conference and Expo \\ Austin, TX, USA. 11-13 June 2015
}

\section{Background}

It has been suggested that nutrient timing strategies may augment training adaptations in active populations. However, collegiate athletes are often restricted by practice schedules, class times and training sessions and, as a result, may not follow recommendations on optimal feeding strategies. Therefore, a survey questionnaire, which examined the nutrient timing habits of athletes, was designed and administered at selected Division I Institutions within the United States.

\section{Methods}

A total of 481 (240 women, 241 men) NCAA Division I athletes representing eleven intercollegiate sports from three universities in three athletic conferences (i.e., Atlantic 10, Atlantic Coast Conference, Conference USA) volunteered to participate as subjects. There were 18 multiple choice questions that addressed nutrient timing habits. The surveys were administered to all athletes during a scheduled training time.

\section{Results}

When asked about breakfast habits 2\% (9/398) reported eating breakfast $\leq$ once per week, while $51 \%(204 / 398)$ reported consuming breakfast 7 days per week. $79 \%$ of all athletes reported feeling hungry prior to training, practice or competition. However, $77 \%$ of all athletes surveyed reported that it was "easy" to eat 1-2 hours prior to competition. A summary of the amount of time prior to practice, training or competition that athletes consumed a full meal is presented in Table 1. When asked if they "snacked" during practice, $24 \%$ of men and $23 \%$ women responded positively. Only $51 \%$ percent of all athletes reported that their athletic department provides post workout or game day nutrition. When asked how soon after practice, training and competition they

'Kinesiology Department, Texas Christian University, Fort Worth, TX, 76129, USA

Full list of author information is available at the end of the article
Table 1 Summary of meal consumption prior to training or competition.

\begin{tabular}{lccc}
\hline Hours Before & Men & Women & Totals \\
\hline 6 hrs. & 5 & 7 & 12 \\
\hline 5 hrs. & 2 & 2 & 4 \\
\hline 4 hrs. & 16 & 22 & 38 \\
\hline 3 hrs. & 62 & 57 & 119 \\
\hline 2 hrs. & 91 & 86 & 177 \\
\hline 1 hr. & 24 & 28 & 50 \\
\hline Totals & 200 & 200 & 400 \\
\hline Total \% Responses & $100 \%$ & $97 \%$ & $99 \%$ \\
\hline
\end{tabular}

consumed a full meal, $2 \%$ responded $15 \mathrm{~min}, 15 \%$ responded $30 \mathrm{~min}, 22 \%$ responded $45 \mathrm{~min}, 44 \%$ responded $1 \mathrm{hr}$ and $17 \%$ responded $2 \mathrm{hr}$. In regard to nutritional periodization, $43 \%$ of men reported that they consume the same number of calories during off-season and in-season with $36 \%$ reporting that they were unsure. Similarly, $22 \%$ of women reported that they eat the same amount of calories during off-season and in-season with $38 \%$ reporting they were unsure.

\section{Conclusions}

It appears as though most athletes consumed breakfast regularly throughout the week. In addition the results suggest that athletes are consuming a meal or snack after training and competition despite the fact that only $51 \%$ of athletes reported their athletic departments provide post-workout nutrition. However, the majority of athletes also reported feeling hungry prior to training. It is suggested that more proactive strategies may need to be employed to optimize training adaptations.

\section{Authors' details}

${ }^{1}$ Kinesiology Department, Texas Christian University, Fort Worth, TX, 76129,

USA. ${ }^{2}$ Exercise \& Sport Science Department, University of Wisconsin - La Crosse, La Crosse, WI, 54603, USA. ${ }^{3}$ Health and Kinesiology Department, Texas A\&M University, College Station, TX 77840, USA. ${ }^{4}$ Division of Health and Human Performance, George Mason University, Fairfax, VA, 22030, USA. 
doi:10.1186/1550-2783-12-S1-P33

Cite this article as: Nystrom et al: Nutrient timing habits of Division I

NCAA athletes. Journal of the International Society of Sports Nutrition 2015

12(Suppl 1):P33.

Submit your next manuscript to BioMed Central and take full advantage of:

- Convenient online submission

- Thorough peer review

- No space constraints or color figure charges

- Immediate publication on acceptance

- Inclusion in PubMed, CAS, Scopus and Google Scholar

- Research which is freely available for redistribution

Submit your manuscript at 